\title{
Magnesium deficiency: effect on bone mineral density in the mouse
} appendicular skeleton

\author{
Helen E Gruber*1, Robert K Rude ${ }^{2}$, L Wei ${ }^{2}$, A Frausto ${ }^{2}$, Barbara G Mills ${ }^{2}$ and \\ H James Norton ${ }^{3}$
}

Address: ${ }^{1}$ Department of Orthopaedic Surgery, Cannon Bldg, 3rd floor, Carolinas Medical Center, PO Box 32861, Charlotte, N.C. 28203, USA, ${ }^{2}$ University of Southern California and the Orthopaedic Hospital, 2025 Zonal Ave., Los Angeles, CA 90033, USA and ${ }^{3}$ Department of Biostatistics, Carolinas Medical Center, PO Box 32861, Charlotte, N.C. 28232, USA

Email: Helen E Gruber* - hgruber@carolinas.org; Robert K Rude - RRude60075@aol.com; L Wei - livvywei@yahoo.com; A Frausto - frausto@usc.edu; Barbara G Mills - ; H James Norton - jnorton@carolinas.org

* Corresponding author

Published: 17 April 2003

BMC Musculoskeletal Disorders 2003, 4:7
Received: 29 January 2003

Accepted: 17 April 2003

This article is available from: http://www.biomedcentral.com/I47I-2474/4/7

(C) 2003 Gruber et al; licensee BioMed Central Ltd. This is an Open Access article: verbatim copying and redistribution of this article are permitted in all media for any purpose, provided this notice is preserved along with the article's original URL.

\begin{abstract}
Background: Dietary magnesium $(\mathrm{Mg})$ deficiency in the mouse perturbs bone and mineral homeostasis. The objective of the present study was to evaluate bone mineral density of the femur in control and $\mathrm{Mg}$-deficient mice.

Methods: $\mathrm{BALB} / \mathrm{c}$ mice aged 28 days at study initiation were maintained on a normal or $\mathrm{Mg}$ deficient $(0.0002 \% \mathrm{Mg})$ diet, and at time points $0,2,4$ or 6 weeks bones were harvested for bone mineral density analysis. Peripheral quantitative computed tomography (PQCT) was used to assess the trabecular metaphyseal compartment and the cortical midshaft.

Results: Although mean total bone density of the femoral midshaft in $\mathrm{Mg}$ deficient mice did not differ significantly from controls throughout the study, the trabecular bone compartment showed significantly decreased mineral content after $4(p<0.00 \mathrm{I})$ and 6 weeks $(\mathrm{p}<0.00 \mathrm{I})$ of $\mathrm{Mg}$ depletion.

Conclusions: This study demonstrates the profound effect of $\mathrm{Mg}$ depletion on the trabecular compartment of bone, which, with its greater surface area and turnover, was more responsive to $\mathrm{Mg}$ depletion than cortical bone in the appendicular skeleton of the mouse.
\end{abstract}

\section{Background}

Several previous epidemiologic studies have demonstrated a positive correlation between dietary $\mathrm{Mg}$ intake and bone density and/or the rate of bone loss during low $\mathrm{Mg}$ intake in humans [1-5]. Magnesium depletion has also been strongly indicated as a risk factor for osteoporosis associated with aging and postmenopausal status [6-8]. Since osteoporosis also occurs with greater frequency in certain populations in which $\mathrm{Mg}$ depletion is also present, such as diabetes mellitus, alcoholism, and malabsorption syndromes [9], further investigations of animal models in which dietary Mg intake is decreased are valuable because they can help us to better understand the relationship of $\mathrm{Mg}$ inadequacy and bone health.

Previous work by our group has shown that in the Mg-depleted mouse hypomagnesemia develops and skeletal Mg content falls significantly [10]. Bone histomorphometry analysis showed that trabecular bone of Mg-depleted mice also shows increased numbers of osteoclasts and reduced numbers of osteoblasts. The present study was conducted in order to compare bone mineral density in the 
trabecular and cortical bone of the mouse femur using peripheral quantitative computed tomography (pQCT). This study demonstrates the profound effect of $\mathrm{Mg}$ depletion on the trabecular compartment of bone, which, with its greater surface area and turnover, was more quickly responsive to Mg depletion than cortical bone in the appendicular skeleton of the mouse.

\section{Methods}

The study presented here was approved by the IACUC of Orthopaedic Hospital. Dietary Mg deficiency was induced for up to 6 weeks in BALB/c female mice (Simonsen Laboratories, Gilroy, CA) aged 28 days at start of the study. Mice were acclimated to the vivarium for one week, and fed tap water and a control or Mg deficient diet as described below ad libitum. Animals were housed individually in 7-inch-high plastic cages with 110 inch $^{2}$ floor area with Sani-chips bedding. The environment was maintained at $20-25^{\circ} \mathrm{C}, 50 \%$ humidity, with $10-15$ room air exchanges per hour and a 12:12-hour light: dark cycle. The experimental diets were instituted after a 1-week acclimation period. Mice were fed either a normal control $\mathrm{Mg}$ diet $(0.06 \%$ as percent of total diet) or a Mg-deficient diet $(0.002 \% \mathrm{Mg})$ (both diets obtained from Harlan Teklad, Madison, WI). Dietary calcium intake was as recommended for mice at $0.05 \%$. The complete composition of the diet has been previously published [11]. Pair feeding was performed in order to keep weight gain as close as possible in the Mg-deficient and control groups, as bone mass is closely correlated with body mass. Control mice were pair-fed with the Mg-deficient mice based on weight of food consumed by the Mg-deficient animals accordingly every day. During the study period, distilled deionized water containing $<0.003 \mathrm{mg} \mathrm{Mg} / \mathrm{dl}$ was used for hydration.

Animals were weighed at start of study and at study terminations. At baseline, and 2, 4 and 6 weeks of study, animals were euthanized, the right femur removed and the left femur harvested for bone mineral density analysis. Peripheral quantitative computed tomography (pQCT) was performed on the excised left femur using a Stratec XCTRM and associated software (Stratec Medizintechnik Gmbh, Pforzheim, Germany. Software version 5.40). The scan was performed at two sites, 12 and 50\% from the distal end of the femur. The positions were verified using scout views and one $0.5-\mathrm{mm}$ slice perpendicular to the long axis of the femur shaft was acquired. The scans were analyzed using a threshold for delineation of the external boundary recommended by the software. The bone mineral density, area and mineral content at each site were reported. Quality control of the machine was monitored by scanning a manufacturer-provided phantom on each day of scan. The coefficient of variations for bone mineral content, area and density were $2.2,3.5$ and $2.8 \%$, respectively.
Statistical analysis employed $\mathrm{SAS}^{\circledR}$ version 8.2 software and used standard methods of analysis including paired and unpaired t-tests and two-way ANOVA with interaction. Data are expressed as means \pm S.D.

\section{Results}

Pair feeding was used to attempt to keep weight changes as close as possible in control and Mg-deficient animals. As shown in Table 1, there was no difference in the initial vs final mean weights for control animals at 2,4 or 6 week study timepoints. In the Mg-deficient animals, there was no difference between initial and final mean weights at 2 weeks or at 4 weeks. In the 6 week group, however, the final weight was significantly less than the mean initial weight of that group $(\mathrm{p}=0.002)$. When mean initial weights were analyzed, the controls and Mg-deficient animals showed no differences in the 4 or 6 week groups. In the 2 week group, however, controls were significantly heavier $(\mathrm{p}=0.01)$. When mean final weights were analyzed, controls and Mg-deficient animals showed no differences in the 2 and 4 week groups; in the 6 week group, controls were significantly heavier than Mg-deficient animals ( $\mathrm{p}<0.001)$. It is unlikely that these body weight differences influenced bone mineral density since changes seen in trabecular bone mineral content between controls and Mg-deficient animals were already present in the 4 week group, a time at which there was no difference in mean weights of these groups.

Femurs from mice aged 28 days at start of this study were assessed with pQCT to determine volumetric bone mineral density (BMD, $\mathrm{mg} / \mathrm{cm}^{3}$ ) of the midshaft and total bone mineral content of the distal femoral metaphyseal (BMC, $\mathrm{mg} / \mathrm{mm}$ ) of control and Mg-deficient animals at baseline (time 0, start of study) and 2, 4 and 6 weeks of study. As shown in Figure 1, BMC was significantly decreased in the metaphysis of Mg-deficient mice. Statistical analysis using ANOVA showed that controls increased significantly over time (with all of the change from baseline to week 2) ( $\mathrm{p}=$ $0.005)$. BMC of femurs from Mg-deficient mice did not change significantly over time, and at weeks 4 and 6 were significantly decreased compared to controls at the same time point $(\mathrm{p}<0.001)$. Bone mineral density $\left(\mathrm{mg} / \mathrm{cm}^{3}\right)$ in the metaphysis was similar in controls and Mg-deficient mice at 2 weeks $[171.4 \pm 25.5$ (8) for controls vs $162.1 \pm$ 47.0 (7) for Mg-deficient animals (means \pm S.D. (n))]. At 6 weeks, however, the mean bone mineral density in Mgdeficient animals was significantly lower than controls $(146.8 \pm 37.9(7)$ vs control level of $153.3 \pm 28(10), p=$ $0.02)$.

In contrast to the metaphyseal compartment, no significant difference could be detected in BMD between controls and Mg-deficient mice at the midshaft (Figure 2). At this site ANOVA analysis showed that there was not a 
Table I: Body Weights at Study Initiation and Completion a

\begin{tabular}{|c|c|c|c|c|c|c|}
\hline $\begin{array}{c}\text { Time } \\
\text { (weeks) }\end{array}$ & Baseline Initial & Baseline Final & Control Initial & Control Final & Low Magnesium Initial & $\begin{array}{c}\text { Low Magnesium } \\
\text { Final }\end{array}$ \\
\hline 0 & $\begin{array}{c}25.4 \pm 1.6 \\
(\mathrm{n}=8)\end{array}$ & $\begin{array}{c}25.7 \pm 1.7 \\
(\mathrm{n}=8)\end{array}$ & & & & \\
\hline 2 & & & $\begin{array}{c}25.5 \pm 1.2 \mathrm{c} \\
(\mathrm{n}=8)\end{array}$ & $\begin{array}{c}25.5 \pm 1.6 \\
(\mathrm{n}=8)\end{array}$ & $\begin{array}{c}23.9 \pm 1.9 \\
(n=8)\end{array}$ & $\begin{array}{c}24.4 \pm 2.5 \\
(n=8)\end{array}$ \\
\hline 4 & & & $\begin{array}{l}25.2 \pm 1.5 \\
(\mathrm{n}=8)\end{array}$ & $\begin{array}{c}23.5 \pm 1.5 \\
(n=8)\end{array}$ & $\begin{array}{c}25.1 \pm 1.5 \\
(n=8)\end{array}$ & $\begin{array}{c}24.0 \pm 2.7 \\
(n=8)\end{array}$ \\
\hline 6 & & & $\begin{array}{c}25.5 \pm 1.4 \\
(n=10)\end{array}$ & $\begin{array}{c}28.2 \pm 3.3 \\
(n=10)\end{array}$ & $\begin{array}{c}24.8 \pm 1.6 \\
(n=7)\end{array}$ & $\begin{array}{c}21.5 \pm 2.9 b \\
(n=7)\end{array}$ \\
\hline
\end{tabular}

a Data are expressed as means \pm S.D. See text for discussion of statistical analysis of data. ${ }^{b}$ Significantly less than corresponding mean Low $\mathrm{Mg}$ Initial weight, $p=0.002$, and significantly less than corresponding control mean final weight, $p<0.00 \mathrm{I}$. ${ }^{c}$ Significantly greater than corresponding Low $\mathrm{Mg}$ initial mean weight, $p=0.001$.

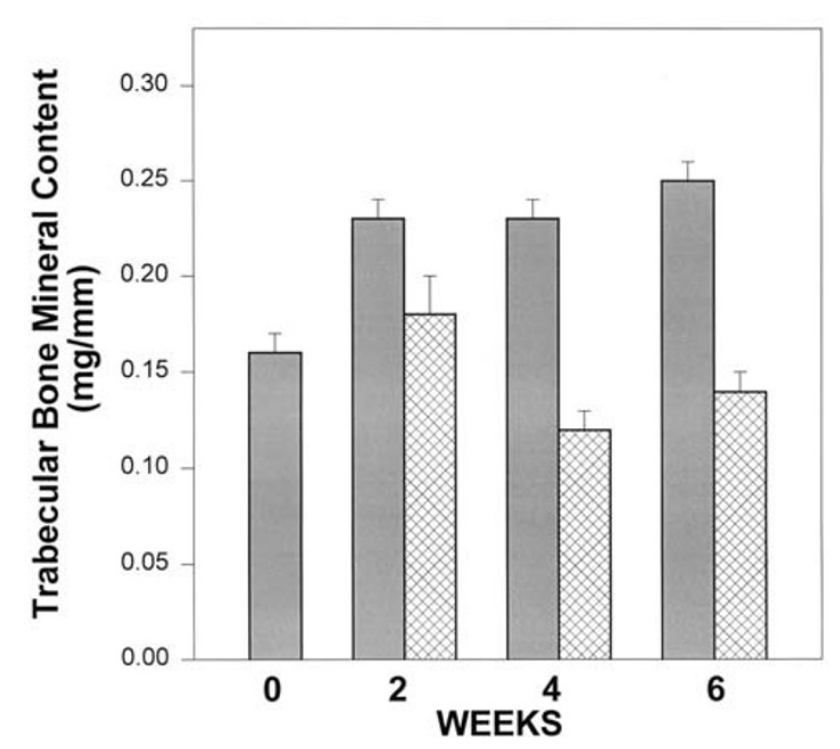

Figure I

Bone mineral content (BMC) of the femoral metaphysis at baseline (time 0 ) and 2, 4 and 6 weeks of study. Solid bars, controls; hatched bars, Mg-deficient mice. BMC of controls increased significantly over the first 2 weeks $(p=0.005)$, with no significant change thereafter. Although there was no change in the BMC of femurs from $\mathrm{Mg}$-deficient mice by the second week, BMC decreased significantly by weeks 4 and 6 $(p<0.00 I)$. (Numbers/group are as noted in Table I)

significant change over time in either control $(\mathrm{p}=0.17)$ or Mg-deficient mice $(p=0.07)$. There was no significant difference between controls or Mg-deficient BMD at 2, 4 or 6 weeks $(=0.53,0.64$ and 0.81 , respectively). Since there is little trabecular bone in the femoral midshaft, trabecular bone mineral content was not evaluated at this site.

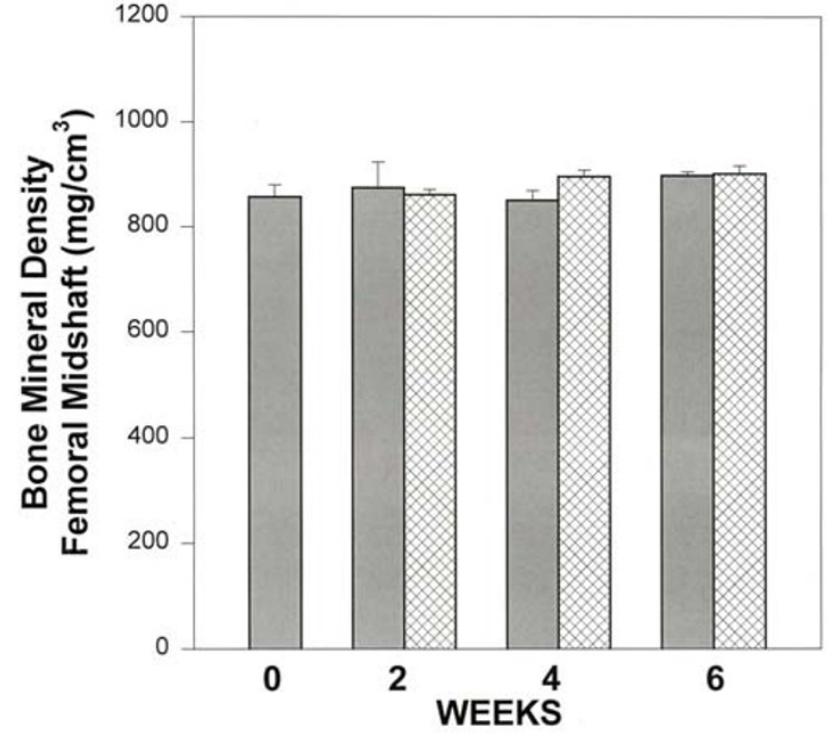

Figure 2

Bone mineral density (BMD) at the femoral midshaft showed no significant difference between control and Mg-deficient mice. (Solid bars, controls; hatched bars, Mg-deficient mice.) (Numbers/group are as noted in Table I)

Mean cortical thickness was also measured at the midshaft site. Control means increased from $0.316 \pm 0.01$ (8) (mean \pm S.D. $(\mathrm{n})$ ) at baseline to $0.323 \pm 0.008$ (10) but showed no significant difference over $0-6$ weeks. Mean cortical thickness similarly did not change significantly in the low Mg mice $(0.311 \pm 0.01$ (8) at baseline; $0.321 \pm$ 0.009 (7) at 6 weeks). 


\section{Discussion}

Although previous studies of the magnesium-deficient mouse had reported that this animal model developed hypocalcemia (similar to humans), more recent work from our laboratory showed that the Mg deficient mouse has significantly elevated serum calcium levels at 4 and 6 weeks of study [10]. Our previous work has also shown that $\mathrm{Mg}$ depletion has a severe effect on the mouse skeleton resulting in impaired bone growth, decreased osteoblast numbers, increased osteoclast numbers and stimulation of cytokine activity in bone. In this model of dietary Mg deficiency, ashing studies have shown that the percent ash Mg content decreases significantly by 3 weeks of depletion and further declines by 6 weeks [10]. (Ash calcium and phosphorus contents, however, are not altered).

In the present study, we have further examined bone in the Mg-deficient murine model using peripheral quantitative computed tomography. Recent studies by Beamer et al have demonstrated that the PQCT technology can be used with precision on the small skeletal bones of the mouse [12]. These authors have also discussed the fact that PQCT data compare well with other methods of assessing bone density such as histomorphometry and dual energy X-ray absorptiometry.

After 4 and 6 weeks of Mg deficiency, BMC of the mouse femur in a site primarily trabecular in nature was significantly lower than that of control animals at these time points. Femoral BMD, however, and femoral cortical midshaft thickness, showed no difference compared to relevant control means. These data demonstrate the profound effect of $\mathrm{Mg}$ depletion on the trabecular compartment of bone, which, with its greater surface area and turnover, was more responsive to $\mathrm{Mg}$ depletion than cortical bone in the appendicular skeleton of the mouse. The general nature of enhanced responsiveness of trabecular bone has been previously noted since trabecular bone not only has greater surface area and greater bone turnover than cortical bone, but also the changes of bone as seen in diseases such as osteoporosis have a greater effect in that compartment [13]. It is of interest to note that a similar pattern of change - decreased BMC but unchanged midshaft BMD was seen in the tibia of mice lacking the transforming growth factor- $\beta 1$ gene studied by Geiser et al [14].

Studies with several animals models subjected to dietary $\mathrm{Mg}$ deficiency show that $\mathrm{Mg}$ deficiency is a risk factor for osteoporosis. A positive correlation between dietary $\mathrm{Mg}$ intake and bone density and/or increased rates of bone loss has been published in several epidemiologic studies [3,5,15-18]. Our understanding of the mechanisms of action at the bone tissue, cell and hormonal level, however, is still incomplete and much remains to be learned about the role of dietary $\mathrm{Mg}$ intake in the maintenance of bone mass.

\section{Conclusions}

This study demonstrates the profound effect of Mg depletion on the trabecular compartment of bone, which, with its greater surface area and turnover, was more responsive to $\mathrm{Mg}$ depletion than cortical bone in the appendicular skeleton of the mouse.

\section{Competing Interests}

None declared.

\section{Authors' Contributions}

RKR was the principal investigator and designed the study and supervised the experiments. HEG wrote the manuscript and submitted the data for statistical analysis. HJN performed the statistical analysis. LYW and AF contributed technical assistance. BM assisted with experimental design and protocols.

\section{Acknowledgements}

This work was supported in part by grant I R03 AG I6398-0I to RKR from the National Institutes of Health and by funds from Orthopaedic Hospital.

\section{References}

I. Angus RM and Sambrook PN Dietary intake and bone mineral density Bone Miner 1988, 4:265-277

2. Freudenheim JL, Johnson NE and Smith EL Relationships between usual nutrient intake and bone-mineral content of women 35-65 years of age: Longitudinal and cross-sectional analysis Am J Clin Nutr 1986, 44:863-876

3. Yano K, Heilbrun LK, Wasnich RD, Hankin JH and Vogel JM The relationship between diet and bone mineral content of multiple skeletal sites in elderly women living in Hawaii Am J Clin Nutr 1985, 42:877-888

4. Tucker K, Kiel DP, Hannan MT and Felson DT Magnesium intake is associated with bone mineral density in elderly women J Bone Miner Res 1995, 10:S466

5. Tucker KL, Hannan MT, Chen H, Cupples LA, Wilson RWF and Kiel $\mathrm{D}$ Potassium, magnesium, and fruit and vegetable intakes are associated with greater bone mineral density in elderly men and women Am J Clin Nutr 1999, 69:727-736

6. Stendig-Lindberg G, Tepper R and Leichter I Trabecular bone density in a two-year controlled trial of peroral magnesium in osteoporosis Magnesium Research 1993, 6:155-163

7. Sojka JE and Weaver CM Magnesium supplementation and osteoporosis Nutr Rev 1995, 53:71-80

8. Cohen $L$ and Kitzes R Infrared spectroscopy and magnesium content of bone mineral in osteoporotic women Isr J Med Sci 1981, 17:| |23-I|25

9. Rude RK Magnesium metabolism In: Principles of Bone Biology (Edited by: Academic Press, San Diego, CA) Bilezikian JP, Raisz L, Rodan G, Markovac J 1996, 277-293

10. Rude RK, Gruber HE, Wei LY, Frausto A and Mills BG Effect on bone and mineral metabolism in the mouse Calcif Tissue Int 2003, 72:32-41

II. Rude RK, Kirchen ME, Gruber HE, Meyer MH, Luck JS and Crawford $\mathrm{DL}$ Magnesium deficiency-induced osteoporosis in the rat: uncoupling of bone formation and bone resorption Magnesium Research 1999, I 2:257-267

12. Beamer WG, Donahue LR, Rosen CJ and Baylink DJ Genetic variability in adult bone density among inbred strains of mice Bone 1996, I 8:397-403

13. Mazess RB Noninvasive methods for quantitating trabecular bone In: The Osteoporotic Syndrome. Detection, Prevention and 
Treatment (Edited by: Avioli LV) Grune \& Stratton, Inc., New York 1983, 85-II4

14. Geiser AG, Zeng QQ, Sato M, Helvering LM, Hirano T and Turner $\mathrm{CH}$ Decreased bone mass and bone elasticity in mice lacking the transforming growth factor- $\beta$ I gene Bone $1998,23: 87-93$

15. New SA, Bolton-Smith C, Grubb DA and Reid DM Nutritional influences on bone mineral density: A cross-sectional study in premenopausal women Am J Clin Nutr 1997, 65:1831-1839

16. New SA, Robins SP, Campbell MK, Martin JCGMJ, Bolton-Smith C Brubb DA, Lee SJ and Reid DM Dietary influences on bone mass and bone metabolism: further evidence of a positive link between fruit and vegetable consumption and bone health? Am J Clin Nutr 2000, 7 I: I42-151

17. Carpenter TO, Barton $C N$ and Park YK Usual dietary magnesium intake in NHANES III is associated with femoral bone mass J Bone Miner Res 2000, I5(SuppI I):S292(Abstract)

18. Wang MC, Moore EC, Crawford PB, Hudes M, Sabry ZI, Marcus R and Bachrach LK Influence of pre-adolescent diet on quantitative ultrasound measurements of the calcaneus in young adult women Osteoporosis Int 1999, 9:532-535

\section{Pre-publication history}

The pre-publication history for this paper can be accessed here:

http://www.biomedcentral.com/1471-2474/4/7/prepub

Publish with Bio Med Central and every scientist can read your work free of charge

"BioMed Central will be the most significant development for disseminating the results of biomedical research in our lifetime. "

Sir Paul Nurse, Cancer Research UK

Your research papers will be:

- available free of charge to the entire biomedical community

- peer reviewed and published immediately upon acceptance

- cited in PubMed and archived on PubMed Central

- yours - you keep the copyright

Submit your manuscript here:

http://www.biomedcentral.com/info/publishing_adv.asp 